American Journal of Applied Sciences 8 (5): 436-440, 2011

ISSN 1546-9239

(C) 2010 Science Publications

\title{
Palm Oil Milling Wastes and Sustainable Development
}

\author{
A.C. Er, Abd. Rahim Md. Nor and Katiman Rostam \\ Development and Environmental Studies, School of Social, \\ Faculty of Social Sciences and Humanities, University Kebangsaan Malaysia, \\ 43600 Bangi, Selangor Darul Ehsan, Malaysia
}

\begin{abstract}
Problem statement: Palm oil milling generates solid wastes, effluent and gaseous emissions. The aim of this study is to assess the progress made in waste management by the Malaysian palm oil milling sector towards the path of sustainable development. Sustainable development is defined as the utilization of renewable resources in harmony with ecological systems. Inclusive in this definition is the transition from low value-added to higher value-added transformation of wastes into resources. Approach: A longitudinal study was carried out from 2003-2010 via, initially a field survey and subsequently a key informant approach with observation as a complementation for both. Results: Solid wastes, inclusive of solid wastes derived from air emissions and palm oil mil effluent, have a utility function with zero wastage. The principal source of effluent is palm oil mill effluent. Treated palm oil mill effluent is utilized for cropland application by plantation-based palm oil mills. However, independent mills discharge treated palm oil mill effluent in accordance to environmental parameters into receiving waterways. Methane is also released by palm oil mill effluent. Biogas from palm oil mill effluent and biomass energy from solid wastes are potential sources of renewable energy in Malaysia. Conclusion: In general, the wastes from palm oil milling are returned to the field for cropland application, utilized in-house or in the plantation, or sold to third parties. Thus, there is progress made towards sustainable development. The addition of new technologies and replacement of old mills will help to reduce the carbon footprint. However, at this juncture, the feed-in tariff for renewable energy is not financially attractive. If the biogas and biomass renewable energy sector were to take-off, enhancement in the value chain would occur and in tandem further progress towards sustainable development can be attained.
\end{abstract}

Key words: Biochemical Oxygen Demand (BOD), sustainable development, solid wastes, palm oil mill effluent, biogas production, biomass energy, renewable energy, Fresh Fruit Bunches (FFBs), Environmental Quality Act (EQA), Certified Emission Reduction (CER)

\section{INTRODUCTION}

Palm oil milling is basically the processing of oil palm Fresh Fruit Bunches (FFBs) into crude palm oil and palm kernel. The by-products or wastes are in the forms of Empty Fruit Bunches (EFBs), mesocarp fibers, shells, Palm Oil Mill Effluent (POME) and boiler ash. The most voluminous and ecologically unfriendly is POME (Saifudin and Fazlili, 2009).

The proliferation of palm oil mills in the 1970s brought about heavy stress on the environment, especially POME. That period has a mean Biochemical Oxygen Demand (BOD) of 25,000 parts per million (ppm) and overly exceeded the parameter limit in the Environmental Quality Act (EQA), Malaysia as listed in Table 1. There was no proven technology to treat POME then. This led to a government-industry initiative to develop indigenous technology to resolve this growing environmental problem (Er, 2011). The synergistic government-industry relationship in pollution abatement is reflected in Table 1 with the gradual tightening of the parameter limits for watercourse discharge (International Law Book Services, 2010).

The aim of this study is to study the progress made by the Malaysian palm oil milling sector in managing its wastes towards the path in sustainable development. Progress is assessed based on waste reduction leading to zero waste or converting wastes into resources, preferably renewable resources, by moving up the value chain. The focus of this study is on environmental management of effluent, solid wastes and air emissions. Emphasis is also given to biogas or biomass renewable energy (as the feedstock is waste) as its development and success have a major environmental impact.

Corresponding Author: A.C. Er, Development and Environmental Studies, School of Social, Faculty of Social Sciences and Humanities, University Kebangsaan Malaysia, 43600 Bangi, Selangor Darul Ehsan, Malaysia Tel: +06-03-89213945 Fax: +06-03-89213334 
Am. J. Applied Sci., 8 (5): 436-440, 2011

Table 1: Second schedule in the EQA in relation to parameter limits for watercourse discharge for palm oil Millers

\begin{tabular}{|c|c|c|c|c|c|c|}
\hline \multirow[b]{2}{*}{$\begin{array}{l}\text { Parameters } \\
\text { (1) }\end{array}$} & \multicolumn{6}{|c|}{ Limits According to Periods of Discharge } \\
\hline & $\begin{array}{l}1-7-1978- \\
30-6-1979 \\
(2)\end{array}$ & $\begin{array}{l}\text { 1-7-1979- } \\
30-6-1980 \\
\text { (3) }\end{array}$ & $\begin{array}{l}1-7-1980- \\
30-6-1981 \\
\text { (4) }\end{array}$ & $\begin{array}{l}\text { 1-7-1981- } \\
31-12-1982 \\
\text { (5) }\end{array}$ & $\begin{array}{l}1-7-1982- \\
31-12-1983 \\
(6)\end{array}$ & $\begin{array}{l}1-1-1984 \text { and } \\
\text { thereafter } \\
\text { (7) }\end{array}$ \\
\hline $\begin{array}{l}\text { Biochemical Oxygen Demand (BOD) } \\
3 \text { day, } 30^{\circ} \mathrm{C} ; \mathrm{mg} \mathrm{L}^{-1}\end{array}$ & 5,000 & 2,000 & 1,000 & 500 & 250 & 100 \\
\hline Chemical Oxygen Demand (COD); mg L ${ }^{-1}$ & 10,000 & 4,000 & 2,000 & 1,000 & - & - \\
\hline Total Solids; $\mathrm{mg} \mathrm{L}^{-1}$ & 4,000 & 2,500 & 2,000 & 1,500 & - & - \\
\hline Suspended Solids; mg L ${ }^{-1}$ & 1,200 & 800 & 600 & 400 & 400 & 400 \\
\hline Oil and Grease; $\mathrm{mg} \mathrm{L}^{-1}$ & 150 & 100 & 75 & 50 & 50 & 50 \\
\hline Ammoniacal Nitrogen; mg L ${ }^{-1}$ & 25 & 15 & 15 & 10 & $150^{*}$ & $150^{*}$ \\
\hline Total Nitrogen; $\mathrm{mg} \mathrm{L}^{-1}$ & 200 & 100 & 75 & 50 & $300 *$ & $200 *$ \\
\hline $\mathrm{pH}$ & $5.0-9.0$ & $5.0-9.0$ & $5.0-9.0$ & $5.0-9.0$ & $5.0-9.0$ & $5.0-9.0$ \\
\hline Temperature ${ }^{\circ} \mathrm{C}$ & 45 & 45 & 45 & 45 & 45 & 45 \\
\hline
\end{tabular}

Note: *: Value of filtered sample; Source: International Law Book Services (2010): 59

Polemics abound in the definition of sustainable development. Development is often associated with improving people's well being (Vijya et al., 2009). Sustainability carries the implication of utilizing and living on renewable resources without damaging the ecosystem. Thus, sustainable development is a marriage of these two concepts (Cunningham and Cunningham, 2006). The definition of sustainable development used in this study is based on the utilization of renewable resources in harmony with ecological systems. In harmony with ecological systems means meeting present needs without compromising in meeting the needs of future generations. Brundtland Report on the definition of sustainable development is the overarching principle (Malakmohammadi, 2009). Inclusive in this definition is the transition from low to higher level of efficiency in production.

\section{MATERIALS AND METHODS}

The research method adopted is a longitudinal study starting from 2003 till 2010. In 2003, a field survey via a structured questionnaire was carried out on 24 respondent mills. This is to obtain a comprehensive overview and understanding of environmental management in palm oil milling. From 2005 onwards till 2010, a shift in approach to key informants was adopted. These key informants are identified based on their knowledge of environmental management in palm oil milling. These data were complemented and supplemented by observation and content analysis with regard to environmental management practices adopted in palm oil mills.

\section{RESULTS AND DISCUSSION}

The analysis and discussion will be based on environmental management of end-of-pipe wastes, namely solid wastes, effluent and air emissions. The last section will focus on biogas or biomass renewable energy generation

Solid wastes: Solid wastes comprise mainly of EFBs, mesocarp fibers and shells. Initially EFBs were incinerated and plantation-based palm oil mills returned the ashes to the field as fertilizer. In the case of independent palm oil mills (do not own a plantation), the ashes were sold to third parties as fertilizer. The Department of Environment discourages incineration due to air pollution. However the older mills, especially independent mills as they do not own a plantation, are allowed to continue with incineration. The increasing demand for EFBs as mulch by small plantations, knowledgeable smallholders and vegetable farmers has led to a vast reduction in incineration. Currently, plantation-based mills return the EFBs to the fields for the superior process of mulching. This is a cost-saving measure as it reduces the dependence on fertilizers as fertilizers are mainly imported to Malaysia. However, the criticisms of mulching are the release of methane into the air when EFBs rot, non-recovery of remnant oil and relatively low value-addition.

The mesocarp fiber and shell materials are used as solid fuel feedstock for steam generation and electricity. The steam generated is used in-house. Likewise, the electricity generated is also used in-house and in addition is supplied to employee housing. Palm oil mills, in general, are self-sufficient in energy generation due to the voluminous solid fuel feedstock available. The fibers and shells are more than sufficient. One of the respondent mills has used the fibers for the production of value-added medium density fiberboards. Nursery owners would also purchase the fibers as bedding material for their plants. Shells, on the other hand, are used as hardening material for the roads in the plantations. High value-added production of activated charcoal from shells by third party shell purchasers also does occur. The Malaysian Palm Oil Board, based on 
the solid wastes generated by palm oil milling, has developed many innovative products. However, not a significant number from the oil palm and palm oil community has adopted the production of these products.

Effluent: Voluminous amount of water is used to process FFBs to crude palm oil. Approximately 50\% of the water utilized results in POME. For every ton of crude palm oil extracted from milling, about 2.5 tons of POME are generated (Sulaiman et al., 2009). Raw POME has a very high organic content and if discharged into receiving waterways, has the potential to cause adverse environmental consequences. In addition, POME is foul smelling and can cause odor pollution. POME is a constitution of three major streams of wastewater, namely sterilizer condensate, clarification wastewater and hydroclone wastewater.

The three most common treatment systems are the ponding system, the open tank digester and extended aeration system and the closed anaerobic digester and land application system. The most popular among these three is the ponding system. Any of these three treatment systems via proper application enables a miller to comply with all EQA parameters as listed in Table 1. Treated POME can either be discharged into receiving waterways or for cropland application. Independent palm oil millers discharging treated POME into receiving waterways has to meet the stringent BOD parameter of $100 \mathrm{mg} \mathrm{L}^{-1}$ or less. For plantation-based palm oil millers, the treated POME channeled for cropland application has to meet the BOD parameter of $5,000 \mathrm{ppm}$ or less. Treated POME at BOD parameter of $5,000 \mathrm{ppm}$ or less, still has high organic nutrient and has been successfully used as fertilizer or soil conditioner. This results in significant savings via lesser importation of fertilizer. In addition, oil palm trees require adequate amount of water to bear (richer) fruits and treated POME is also an additional water source during the dry periods in Malaysia.

The advancement in POME treatment technologies in the 1990s led to the introduction of the decanter-drier system. As clarification wastewater is the most copious amount in POME, the decanter-drier system has helped to reduce the volume of effluent and clarification sludge. The dried solids are harnessed via a rotary drier with heat obtained from the boiler exhaust system. The dried solids are used as soil conditioner and also as animal feed. An observation on one of the independent mill respondents revealed that the pressed crude oil mixture is separated by a later version of the decanterdrier into an oil phase, dried solid cake and virtually oil-free wastewater. The oil-free wastewater complies with the BOD requirement for discharge into receiving waterways. The latest development with the advent of evaporation and membrane technology has led to zero discharge.

The implication is the older mills have a higher pollution load. The later mills would have the advantage of better production and treatment technologies and therefore less waste generation. However, all the POME waste is utilized with the exception of methane (discuss in later sections) and independent mills that have to discharge the treated POME into receiving waterways. If the latest technologies like evaporation and membrane technologies were adopted, there would be zero discharge.

Air emissions: The two major problems associated with air emission are biogas released by POME in the ponds during anaerobic digestion and boiler ash. The biogas is a mixture of mainly methane and carbon dioxide. Methane, a greenhouse gas, is 20 times more harmful than carbon dioxide on climate change.

The composition of boiler ash is a mix of clinkers and ash. Boiler ash is utilized as fertilizer for cropland application or for application on the road network in the plantation. Some of the palm oil mills use the boiler ash as a floor-cleansing agent. As the floor of the palm oil mills tend to be oily, the application of boiler ash on the oily floor results in a weak potash soap. This is then washed away with water.

Biogas and biomass renewable energy: Sime Darby Plantations first initiated the harvesting of biogas from POME ponds in the 1980s. However, at that juncture, it remained in the developmental stage as there is no justification for its economic viability. The signing of the Kyoto Protocol and in tandem the introduction of the Clean Development Mechanism (CDM) and the tax credit claimable for Certified Emission Reduction (CER) (Upenda, 2009) reignited the interest for biogas or biomass renewable energy in the later 2010s. Large vertically integrated oil palm and palm oil companies like KL Kepong (Er, 2010) and smaller groups like Bell Corp Sdn. Bhd. (Ooi, 2010) have initiated biogas renewable energy projects. However, some quarters claimed that CER is difficult to obtain.

Biogas from POME (Rozliza et al., 2009) and biomass energy from solid wastes have been propounded as a renewable energy source for Malaysia. Biomass power potential is expected to increase to 1,335 megawatts if all the palm biomass is maximized to the fullest (The Star 22 March 2010. Tenaga Nasional Berhad, the owner of the national grid, has 
committed to purchase renewable energy from small renewable energy producers. Palm biogas or biomass renewable energy would fall into this category (Vijaya et al., 2010).

An immediate obstacle to the take-off or acceleration phase for biogas or biomass renewable energy is the price offered to Green Independent Power Producers (IPPs) for feed-in tariff to the national grid. The feed-in tariff at 21 sen per kilowatt is far below the price range of 29 sen to 40 sen per kilowatt required. The price range is due to location and the required connectivity infrastructure. This is similar to the food value versus fuel value debate for biofuel (Er, 2010). If the feed-in tariff is below the Return On Investment (ROI) for a biogas or a biomass project, the project would not take-off. However, the coming into force of the yet to be enacted Renewable Energy Act may change the equilibrium. If the feed-in tariff for renewable energy is higher than the ROI on a long-term contractual period, the advent of the takeoff phrase is highly possible. Peninsular Malaysia and the state of Sabah with the exception of the state of Sarawak due to its mammoth Bakun hydro project, have to increase energy generation due to capacity limitation and the nation's increasing demand. The government's move towards green technology may be the catalyst needed to boost demand for biogas or biomass renewable energy. The development of biogas or biomass renewable energy is seen to the ecologically friendly for the oil palm and palm oil sector as the carbon footprint can be reduced drastically. From a lifecycle assessment perspective, it is an additional step in aiding palm biofuel to comply with the European Union's Renewable Energy Directive. Compliance means certified eligibility for mandatory blending for biofuel in European Union's 28 member countries.

Biogas production does not face the problem of scale as palm oil milling is carried out virtually on a daily basis. The amount of POME from a mill and consequently the amount of methane generated is sufficient for a biogas plant. However, for biomass energy plant, the EFB feedstock from a palm oil mill is insufficient and additional feedstock is required. The collection and collation of EFB feedstock is therefore in the realm of large plantation-based vertically integrated companies. A few palm oil mills in the nearby vicinity allows for economies of scale for feedstock. If otherwise, the transportation cost for EFBs would hike up the feedstock cost.

\section{CONCLUSION}

In general, the wastes generated from palm oil milling are returned to the field for cropland application, utilized in-house or in the plantation, or sold to third parties for value-addition. The entire spectrum of solid wastes, inclusive of solid wastes derived from air emissions and POME, has a utility function and none is wasted. However, the main criticism is the relatively low value-addition of such activities. Likewise, treated POME is utilized for cropland application with the exception of independent millers that have no alternative but to discharge into receiving waterways. The treatment technologies for POME allow for the above without breaching the EQA parameters. The addition of new technologies, replacement of old mills at the end of the mills' lifespan and the construction of new mills will reduce the carbon footprint. New technologies and new plants will contribute to higher level of resource utilization efficiency, higher oil recovery and lesser effluent. This, in turn, places the palm oil milling sector towards the path of sustainable production. Malaysia's strategic focus in developing renewable energy and the attraction of CER tax credit under CDM may prove to be the catalyst in the take-off of the biogas or biomass sector in the oil palm and palm oil production chain. However, impediments like the low feed-in-tariff make the fuel value much lower than the required ROI. If the required ROI were attained, methane and biomass wastes would be transformed into a relatively higher value resource.

\section{REFERENCES}

Cunningham, W.P. and M.A. Cunningham, 2006. Principles of Environmental Science: Inquiry and Applications. 4th Edn., McGraw Hill, New York, ISBN: 0073304468, pp: 410.

Er, A.C., 2010. The Challenges Facing the Palm Oil Biofuel Sector in Malaysia. Asian Profile, pp: 399404. ISBN: 03048675

Er, A.C., 2011. A comparative analysis of the brazillian bioethanol sector and the malaysian paslm biofuel sector. Asian Soc. Sci., 7: 4-8. ISSN: 1911-2017, E-ISSN: 1911-2025

International Law Book Services, 2010. Environmental Quality Act 1974 (Act 127). Petaling Jaya, Selangor Darul Ehsan. http://www.worldcat.org/title/environmentalquality-act-1974-act-127-subsidiary-legislation-asat-5th-august-2003/oclc/61269628 
Malakmohammadi, I., 2009. Toward clean green sustainable development to prevent the first foods world war, changing authoritative-public extension to literalized-partnership extensions system. Am. J. Agri. Biol. Sci., 4: 49-62. DOI: 10.3844/ajabssp.2009.49.62

Ooi, T.C., 2010. Millers can help meet gas shortage. Business Times, New Straits Times. http://findarticles.com/p/news-articles/new-straitstimes/mi_8016/is_20100206/millers-meet-gasshortage/ai_n49429044/

Rozliza, S., O.H. Ahmed, M.A. Nik M.A. Majid and MB. Jalloh, 2009. Reduction of ammonia volatilization through mixing urea with humic and fulvic acids isolated from palm oil mill effluent sludge. Am. J. Environ. Sci., 5: 382-386. DOI: 10.3844/ajessp.2009.382.386

Saifudin, N. and S.A. Fazlili, 2009. Effect of microwave and ultrasonic pretreatments on biogas production from anaerobic digestion of palm oil mill effluent. Am. J. Eng. Applied Sci., 2: 139-146. DOI: 10.3844/ajeassp.2009.139.146
Sulaiman, A., M.R. Zakaria, M.A. Hassan, Y. Shirai and Z. Busu. 2009. Co-Digestion of Palm Oil Mill Effluent and Refined Glycerin Wash Water for Chemical Oxygen Demand Removal and Methane Production. Am. J. Environ. Sci., 5: 639-646. DOI: 10.3844/ajessp.2009.639.646

Upenda, A., 2009. Emissions trading is free market environmentalism the answer? Am. J. Econ. Bus. Admin., $\quad 1$ : 213-218. $\quad$ DOI: 10.3844/ajebasp.2009.213.218

Vijaya, S., A.N. Ma and Y.M. Choo, 2010. Capturing biogas: A means to reduce green house gas emissions for the production of crude palm oil. Am. J. Geosci., 1: 1-6. DOI: 10.3844/ajgsp.2010.1.6

Vijya, S., A.N. Ma and Y.M. Choo, 2009. A gate to gate assessment of environmental performance for production of crude palm kernel oil using life cycle assessment approach. Am. J. Environ. Sci., 5: 267272. DOI: 10.38444/ajessp.2009.267.272 